\title{
STUDI FAAL PARU DAN KEBIASAAN MEROKOK PADA PEKERJA YANG TERPAPAR DEBU PADA PERUSAHAAN KONSTRUKSI DI SURABAYA
}

\author{
Mardliyatus Sholihah, Abdul Rohim Tualeka \\ Departemen Keselamatan dan Kesehatan Kerja \\ Fakultas Kesehatan Masyarakat Universitas Airlangga \\ E-mail: mardliyatussholihah@yahoo.com
}

\begin{abstract}
Dust exposure received by workers can affect workers's pulmonary function and health condition affected by many factors. This observation conducted on construction. The purpose of this research was identify description about pulmonary function and smoking habit at construction workers. Researcher used cross sectional study. The sample of this research was total population of finishing workers as much as 18 workers who doing construction project in Surabaya. Measurement of dust concentration conducted on three poin, by source of the dust, where workers are working and the outmost point. Research used questionnaires, measurement and inspection. The result of pulmonary function showed that six workers had lung function disorder. Pulmonary function measurement at workers used FEV, and FVC to be the parameter. The result of measurement on point $A$ is $1.6865 \mathrm{mg} / \mathrm{m}^{3}$, on point $B$ is $1.3227 \mathrm{mg} / \mathrm{m}^{3}$ and on point $C$ is $1.0625 \mathrm{mg} / \mathrm{m}^{3}$. Many workers complained that they felt cough in the morning and suffered about eyes irritation. Based on the result of pulmonary function measurement, the conclution is 4 workers had light obstruction and 2 workers had light restriction. Based on measurement, the average of total dust in the project area is $1.3425 \mathrm{mg} / \mathrm{m}^{3}$. Lung function disorder caused by smoking habit. The workers could stop smoking habit and reduce amount.
\end{abstract}

Keywords: pulmonary function, dust, smoking, construction

\begin{abstract}
ABSTRAK
Paparan debu yang diterima oleh para pekerja dapat mempengaruhi kondisi faal paru dan kondisi kesehatan seseorang yang dipengaruhi berbagai macam faktor. Penelitian dilakukan pada perusahaan konstruksi. Tujuan penelitian ini adalah mengidentifikasi gambaran faal paru dan kebiasaan merokok pada pekerja konstruksi. Penelitian ini termasuk penelitian observasional dengan menggunakan desain penelitian cross sectional. Sampel penelitian adalah total populasi pekerja bagian finishing sebanyak 18 pekerja yang sedang melakukan pengerjaan proyek di Surabaya. Pengukuran kadar debu dilakukan pada tiga titik, yaitu sumber debu, tempat pekerja bekerja dan titik terluar. Peneliti menggunakan kuesioner, pengukuran dan pemeriksaan. Hasil pemeriksaan faal paru menunjukkan sebanyak 6 pekerja memiliki gangguan faal paru. Pengukuran faal paru pada pekerja menggunakan parameter $\mathrm{FEV}_{1}$ dan $\mathrm{FVC}$. Hasil pengukuran debu pada titik $\mathrm{A}$ didapatkan hasil $1,6865 \mathrm{mg} / \mathrm{m}^{3}$, titik B sebesar $1,3227 \mathrm{mg} / \mathrm{m}^{3}$ dan titik C sebesar $1,0625 \mathrm{mg} / \mathrm{m}^{3}$. Pekerja mengeluhkan gangguan saluran pernapasan berupa batuk pada pagi hari dan menderita iritasi mata. Berdasarkan hasil pemeriksaan faal paru dapat disimpulkan bahwa 4 pekerja mengalami gangguan obstruksi ringan dan 2 pekerja mengalami restriksi ringan. Hasil pengukuran kadar debu di area proyek hasil total debu rata-rata 1,3425 mg/m³. Gangguan faal paru pekerja dipengaruhi kebiasaan merokok yang dilakukan oleh pekerja. Pekerja diharapkan menghentikan kebiasaan merokok dan mengurangi jumlahnya.
\end{abstract}

Kata kunci: faal paru, debu, merokok, konstruksi

\section{PENDAHULUAN}

Indonesia merupakan salah satu negara berkembang yang sedang melakukan pembangunan di berbagai sektor. Salah satunya adalah pembangunan fisik. Dengan adanya pembangunan fisik mendorong munculnya banyak perusahaan jasa konstruksi yang terus-menerus melakukan perkembangan dalam ilmu maupun teknologi (Hidayat, 2007).
Pekerja konstruksi dalam melakukan pekerjaannya dipengaruhi oleh beberapa faktor yang mempengaruhinya. Faktor tersebut diantaranya adalah faktor fisis, kimiawi, biologis, fisiologis atau ergonomis, mental dan psikologis. Beberapa faktor tersebut dapat bersifat negatif, sehingga dapat merugikan pekerja. Tetapi, apabila faktor negatif tersebut dapat diolah sedemikian rupa maka akan dapat menimbulkan suatu manfaat (Hidayat, 2007). 
Debu merupakan salah satu faktor kimiawi yang dapat mempengaruhi pekerja dalam melakukan pekerjaannya. Debu dalam pekerjaan konstruksi didapatkan dari pengerjaan bangunan, perobohan, penggalian dan lainnya. Apabila debu tersebut masuk melalui saluran pernapasan dan masuk ke dalam paru, maka dapat berakibat terganggunya fungsi paru (Yulaekah, 2007).

Terganggunya fungsi paru dapat mengakibatkan munculnya gangguan pada saluran pernapasan. Gangguan pada saluran napas dapat berupa gangguan fungsi paru, berupa obstruksi, restriksi dan campuran. Dapat juga berupa keluhan subyektif seperti keluhan batuk, asma, flu dan beberapa penyakit paru (Imaduddin, 2012).

Menurut Yulaekah (2007), International Labour Organization (ILO) tahun 2005 memperkirakan insiden rata-rata penyakit paru akibat kerja sekitar satu kasus per 1000 pekerja setiap tahun. Data World Health Organization (WHO) menunjukkan bahwa pada negara berkembang setidaknya 400 sampai 500 juta orang terserang penyakit pernapasan dari akut sampai kronis. Jenis penyakit flu dan bronkhitis merupakan penyakit terbanyak dengan persentase 30 sampai 40 persen yang menimpa tenaga kerja (Yulaekah, 2007).

Di Indonesia terdapat banyak kasus mengenai gangguan saluran pernapasan yang merupakan penyakit akibat kerja. Salah satunya kasus pada PT Sibelco Lautan Minerals tahun 2007 sampai dengan tahun 2011, yakni 7 dari 10 pekerja bagian plant mengeluhkan menderita batuk kering, sesak napas dan kelelahan umum. Sedangkan, pada PT Massen Toys Indonesia di Jombang, terdapat keluhan akan saluran pernapasan sebesar $75 \%$ dari total 80 responden. Keluhan tersebut berupa batuk kering, hidung tersumbat, sesak napas dan nyeri tenggorokan (Imaduddin, 2012).

Tahun 2002, Penyakit Paru Obstruksi Kronik (PPOK) merupakan penyakit penyebab kematian dengan urutan kedua. Berdasarkan hasil analisis surveilans penyakit tidak menular pada 5 rumah sakit di Indonesia (Jawa Barat, Jawa Tengah, Jawa Timur, Lampung dan Sumatera Selatan), menunjukkan kasus PPOK sebanyak 35\%, asma 33\% dan kanker paru 30\% (Rahman et al, 2008).

Berdasarkan uraian latar belakang, maka penulis tertarik untuk melakukan penelitian yang berjudul "Studi Faal Paru dan Kebiasaan Merokok pada Pekerja yang Terpapar Debu pada Perusahaan Konstruksi di Surabaya". Penulisan penelitian bertujuan mengidentifikasi kondisi faal paru pekerja dan kebiasaan merokok pekerja yang terpapar debu pada perusahaan konstruksi di Surabaya.

\section{METODE}

Penelitian menggunakan desain studi cross sectional. Penelitian dilakukan pada proyek pembangunan gedung bertingkat yang sedang dikerjakan oleh PT X di Surabaya. Pengambilan data, pengukuran dan pemeriksaan dimulai pada bulan Mei 2015. Pemeriksaan faal paru dan pengukuran kadar debu dilakukan oleh tenaga ahli dari balai UPTK3.

Populasi penelitian merupakan pekerja finishing PT X, dengan total pekerja sebanyak 45 pekerja. Diberlakukan kriteria inklusi untuk menjadi sampel penelitian. Kriteria inklusi yang ditetapkan adalah umur pekerja harus berumur 17 sampai dengan 45 tahun. Sehingga, didapatkan sampel penelitian sebanyak 18 pekerja.

Pengambilan data dilakukan melalui data primer dan data sekunder. Data primer didapatkan dari hasil kuesioner, pemeriksaan faal paru dan pengukuran kadar debu. Kuesioner tersebut berisi tentang data pribadi responden, keluhan-keluhan yang diderita responden, riwayat penyakit dan sebagainya. Pemeriksaan faal paru dilakukan dengan menggunakan spirometer, dengan memperhatikan parameter $\mathrm{FEV}_{1}$ dan FVC. Pengukuran kadar debu menggunakan alat High Volume Dust Sampler (HVDS). Pengukuran dilakukan pada tiga titik, yaitu sumber debu, aktivitas pekerja dalam bekerja dan titik terluar dari area proyek. Data sekunder yang diperoleh antara lain data pekerja dan gambaran perusahaan.

Variabel penelitian yang dijelaskan oleh peneliti diantaranya adalah kondisi faal paru pekerja, kebiasaan merokok dan kadar debu. Kondisi faal paru pekerja didapatkan berdasarkan parameter $\mathrm{FEV}_{1}$ dan FVC. Kondisi faal paru diidentifikasi berdasarkan karakteristik pekerja. Karakteristik pekerja tersebut diantaranya adalah umur, lama kerja dan masa kerja. Kadar debu dilakukan pengukuran pada tiga titik.

\section{HASIL}

Kondisi faal paru dikategorikan menjadi 2, yaitu normal dan gangguan. Gangguan faal paru dapat berupa restriksi atau obstruksi, sesuai dengan hasil pengukuran $\mathrm{FVC}$ dan $\mathrm{FEV}_{1}$. Berikut adalah hasil pemeriksaan faal paru pada 18 pekerja finishing PT $\mathrm{X}$. 
Tabel 1. Hasil Pengukuran Faal Paru, Umur dan Masa Kerja

\begin{tabular}{ccrl}
\hline Responden & Umur & $\begin{array}{c}\text { Masa kerja } \\
\text { (bulan) }\end{array}$ & $\begin{array}{c}\text { Status faal } \\
\text { paru }\end{array}$ \\
\hline A & 20 & 8 & Normal \\
B & 20 & 8 & Normal \\
C & 24 & 12 & Normal \\
D & 29 & 8 & Normal \\
E & 26 & 1 & Normal \\
F & 25 & 6 & Normal \\
G & 39 & 2 & $\begin{array}{l}\text { Restriksi } \\
\text { ringan }\end{array}$ \\
H & 31 & 18 & Normal \\
I & 26 & 4 & Obstruksi \\
& & & ringan \\
J & 20 & 2 & Normal \\
K & 23 & 18 & Normal \\
L & 30 & 12 & $\begin{array}{l}\text { Restriksi } \\
\text { ringan }\end{array}$ \\
M & 32 & 4 & Obstruksi \\
& & & ringan \\
N & 28 & 12 & Normal \\
O & 24 & 7 & Normal \\
P & 23 & 1 & Normal \\
Q & 40 & 3 & Restriksi \\
R & & & ringan \\
& 36 & 15 & Restriksi \\
ringan
\end{tabular}

Berdasarkan Tabel 1 didapatkan hasil pemeriksaan faal paru pada pekerja, umur dan masa kerja. Tabel 1 menunjukkan pekerja dengan gangguan faal paru didapatkan sebanyak 6 pekerja dengan persentase $33,3 \%$. Sedangkan, pekerja dengan kondisi faal paru normal sebanyak 12 pekerja dengan persentase $66,7 \%$ dari total responden. Sebanyak 6 pekerja yang mengalami gangguan faal paru. Jenis gangguan faal paru pada pekerja tersebut diantaranya adalah obstruksi ringan dan restriksi ringan. Pekerja dengan gangguan restriksi ringan sebanyak 4 pekerja, sedangkan 2 pekerja lainnya mengalami obstruksi ringan.

Umur pekerja dikategorikan menjadi 3 kategori, yaitu muda, menengah dan matang. Kategori umur muda dimulai dari umur 17 tahun sampai dengan 25 tahun. Umur menengah dimulai dari umur 26 tahun sampai dengan 35 tahun. Sedangkan, kategori matang dimulai umur 36 tahun sampai dengan 45 tahun.

Pekerja dengan kategori umur muda sebanyak 7 pekerja dengan persentase $38,9 \%$. Pekerja dengan kategori umur menengah memiliki frekuensi yang sama dengan kategori umur muda yaitu sebanyak 7 pekerja dengan persentase 38,9\%. Kategori umur matang didapati sebanyak 4 pekerja atau sebesar $22,2 \%$ dari total populasi.

Pekerja dengan kategori umur muda, 100\% pekerjanya memiliki kondisi faal paru normal. Pekerja dengan kategori umur menegah dan mengalami gangguan faal paru sebanyak 3 pekerja dengan persentase $42,9 \%$, sedangkan kondisi faal paru normal sebesar 4 pekerja atau $42,9 \%$ dari total pekerja dengan umur menengah. Pekerja dengan kategori umur matang dan mengalami gangguan faal paru sebanyak 3 pekerja dengan persentase $75 \%$, sedangkan pekerja dengan faal paru normal sebanyak 1 orang dengan persentase $25 \%$ dari total pekerja dengan kategori umur matang.

Masa kerja pekerja dikategorikan menjadi 2 kategori, yaitu kurang dari 6 bulan dan lebih dari sama dengan 6 bulan. Sehingga, didapatkan distribusi frekuensi pekerja sesuai dengan total 18 responden. Pekerja dengan kategori masa kerja kurang dari 6 bulan sebanyak 7 pekerja, dengan persentase $38,9 \%$. Sedangkan, pekerja dengan masa kerja lebih dari sama dengan 6 bulan berjumlah 11 pekerja atau $61,1 \%$ pekerja dari total 18 pekerja.

Pekerja dengan masa kerja kurang dari 6 bulan dan mengalami gangguan faal paru sebesar 3 pekerja atau sebesar $42,9 \%$ dari total pekerja dengan masa kerja kurang dari 6 bulan. Pekerja dengan masa kerja kurang dari 6 bulan dan memiliki kondisi faal paru normal sebanyak 4 pekerja dengan persentase $57,1 \%$. Sedangkan, pekerja dengan masa kerja kurang dari 6 bulan dan mengalami kondisi faal paru yang normal sebanyak 4 pekerja dengan persentase $57,1 \%$. Pekerja dengan masa kerja lebih dari sama dengan 6 bulan dan mengalami gangguan faal paru sebanyak 3 pekerja dengan persentase $27,3 \%$. Pekerja yang memiliki masa kerja lebih dari sama dengan 6 bulan dan memiliki kondisi faal paru normal sebanyak 8 pekerja atau dengan persentase $72,2 \%$ dari total pekerja yang bermasa kerja lebih dari sama dengan 6 bulan.

Lama paparan dikategorikan menjadi 2, yaitu lama paparan kurang dari sama dengan 8 jam dan lama paparan lebih dari 8 jam kerja. Pengkategorian tersebut berdasarkan lama kerja pekerja yang sudah diatur. Pekerja dengan lama paparan kurang dari sama dengan 8 jam sebanyak 4 pekerja dengan persentase $22,2 \%$. Sedangkan, pekerja dengan lama paparan lebih dari 8 jam sebesar $77,8 \%$ dari total pekerja, atau berjumlah 14 pekerja.

Pekerja dengan masa kerja kurang dari sama dengan 8 jam dan mengalami gangguan faal paru sebanyak 2 pekerja dengan persentase $50 \%$ dari 
total pekerja yang memiliki lama paparan kurang dari 8 jam. Pekerja dengan lama paparan kurang dari sama dengan 8 jam dengan kondisi faal paru normal memiliki frekuensi yang sama dengan pekerja yang mengalami gangguan, yakni sebanyak 2 pekerja. Pekerja dengan lama paparan lebih dari 8 jam dan mengalami gangguan faal paru sebanyak 4 pekerja dengan persentase sebesar $28,6 \%$, sedangkan pekerja dengan faal paru normal sebanyak 10 pekerja atau $71,4 \%$ dari total pekerja dengan lama paparan lebih dari 8 jam.

Berdasarkan total 18 pekerja, 13 pekerja memiliki kebiasaan merokok. Pekerja dengan kebiasaan merokok memiliki lama rokok dan banyaknya batang yang berbeda-beda setiap pekerjanya. Berikut merupakan distribusi faal paru berdasarkan kebiasaan merokok.

Tabel 2. Distribusi Faal Paru Pekerja Berdasarkan Kebiasaan Merokok

\begin{tabular}{lccccr}
\hline \multirow{2}{*}{$\begin{array}{c}\text { Kebiasaan } \\
\text { Merokok }\end{array}$} & \multicolumn{4}{c}{ Faal Paru } & \\
\cline { 2 - 5 } & \multicolumn{2}{c}{ Normal } & \multicolumn{2}{c}{ Gangguan } & N \\
\cline { 2 - 5 } & $\mathbf{n}$ & $\mathbf{\%}$ & $\mathbf{n}$ & $\mathbf{\%}$ & \\
\hline Tidak & 5 & 100 & 0 & 0 & 5 \\
Ya & 7 & 58.3 & 6 & 42.6 & 13 \\
\hline Total & 12 & 66.7 & 6 & 33.3 & 18 \\
\hline
\end{tabular}

Berdasarkan Tabel 2, didapatkan hasil bahwa pekerja yang tidak memiliki kebiasaan merokok tidak memiliki gangguan faal paru. Hal tersebut menunjukkan bahwa pekerja yang tidak memiliki kebiasaan merokok memiliki kondisi faal paru normal. Sedangkan, pekerja dengan kebiasaan merokok dan mengalami kondisi faal paru sebantak 6 pekerja dengan persentase $42.6 \%$, dan pekerja dengan faal paru normal sebanyak 7 pekerja atau sebesar $58.3 \%$ dari total pekerja yang memiliki kebiasaan merokok.

Kadar debu pada area proyek konstruksi diukur menggunakan alat HVDS (High Volume Dust Sampler). Pengukuran kadar debu pada perusahaan konstruksi dilakukan pada 3 titik. Ketiga titik tersebut merupakan sumber debu, tempat aktivitas pekerja melakukan pekerjaan dan titik terluar dari area kerja. Ketiga titik pengukuran tersebut dilakukan pada titik A, titik B dan titik C.

Berdasarkan hasil pengukuran menggunakan alat HVDS, didapatkan hasil pengukuran pada titik pengukuran A sebesar $1,6865 \mathrm{mg} / \mathrm{m}^{3}$. Kadar debu pada titik B didapatkan hasil pengukuran titik B, $1,3227 \mathrm{mg} / \mathrm{m}^{3}$. Sedangkan, pada titik pengukuran $\mathrm{C}$ didapatkan hasil $1,0625 \mathrm{mg} / \mathrm{m}^{3}$. Berdasarkan hasil pengukuran 3 titik tersebut, didapatkan hasil ratarata ketiga titik sebesar $1,3452 \mathrm{mg} / \mathrm{m}^{3}$. Rata-rata dari ketiga titik tersebut merupakan hasil penjumlahan titik A, B dan $\mathrm{C}$ kemudian dibagi 3, sehingga mendapatkan hasil rata-rata kadar debu.

Tabel 3. Hasil Pengukuran Kadar Debu

\begin{tabular}{cc}
\hline Lokasi Pengukuran & Kadar Debu $\left(\mathbf{m g} / \mathbf{m}^{\mathbf{3}}\right)$ \\
\hline Titik A & 1,6865 \\
Titik B & 1,3227 \\
Titik C & 1,0625 \\
\hline
\end{tabular}

\section{PEMBAHASAN}

Undang-undang Nomor 18 Tahun 1999 menyatakan bahwa pekerjaan konstruksi merupakan keseluruhan atau sebagian rangkaian kegiatan perencanaan dan/atau pelaksanaan beserta pengawasan yang mencakup pekerjaan arsitektural, sipil, mekanikal, elektrikal dan tata lingkungan masing-masing beserta kelengkapannya, untuk mewujudkan suatu bangunan atau bentuk fisik lain. Jasa konstruksi ialah salah satu kegiatan yang termasuk dalam bidang ekonomi, sosial dan budaya yang berperan penting dalam usaha mencapai berbagai sarana dengan tujuan menunjang terwujudnya pembangunan nasional (Undang-undang Nomor 18 Tahun 1999 tentang Jasa Konstruksi).

Pekerjaan konstruksi dipengaruhi oleh berbagai faktor yang menyertainya. Faktor-faktor tersebut menurut Hidayat (2007) adalah faktor fisis, faktor kimiawi, biologis, fisiologis atau ergonomis, mental dan psikologis. Faktor kimiawi merupakan salah satu faktor yang dapat mempengaruhi tenaga kerja. Faktor kimia dalam bidang konstruksi yang dimaksud merupakan debu. Debu dapat mempengaruhi kesehatan saluran pernapasan dan kesehatan paru individu.

Pemeriksaan fisiologi atau faal paru yang dilakukan pada pekerja PT X meliputi pemeriksaan $\mathrm{FEV}_{1}$ (Forced Expiratory Volume 1 second) dan FVC (Forced Vital Capacity). Menurut West (2010) $\mathrm{FEV}_{1}$ merupakan volume gas yang dikeluarkan dalam waktu 1 detik melalui jalan ekspirasi paksa setelah inspirasi penuh. Sedangkan FVC merupakan volume total gas yang dikeluarkan setelah inspirasi penuh secara paksa.

Pemeriksaan fungsi paru bertujuan untuk melakukan deteksi penyakit paru, gangguan pernapasan sebelum bekerja dan menemukan penyakit secara dini sehingga dapat dilakukan pencegahan. Pemeriksaan fungsi paru dilakukan 
dengan menggunakan alat portable spyrometer. Pemeriksaan faal paru dengan menggunakan parameter $\mathrm{FEV}_{1}$ dan $\mathrm{FVC}$ adalah pemeriksaan yang sederhana dan sering kali informatif, bersifat abnormal pada banyak penderita paru dan bermakna apabila menilai progres penyakit (West, 2010).

Berdasarkan hasil pemeriksaan faal paru pekerja menggunakan alat spirometer, didapatkan hasil beberapa pekerja mengalami gangguan faal paru, berupa obstruksi ringan dan restriksi. Penentuan gangguan faal paru ditentukan oleh nilai persen (\%) dari $\mathrm{FEV}_{1}$ dan juga FVC. Penderita obstruksi ringan, mengalami penurunan $\% \mathrm{FEV}_{1}$, pada kondisi faal paru nomal nilai $\mathrm{FEV}_{1}$ harus lebih dari sama dengan $75 \%$. Sedangkan, penderita obstruksi ringan nilai $\% \mathrm{FEV}_{1}$ dimulai dari 74 sampai dengan 60 . Pada penderita restriksi nilai\% FVC-nya lah yang mengalami penurunan. Faal paru normal memiliki nilai FVC lebih dari sama dengan 80 , sedangkan penderita restriksi ringan dimulai dari 79 sampai dengan 60.

Gangguan ventilasi fungsi paru adalah suatu keadaan berkurangnya jumlah udara yang masuk dalam paru dari jumlah normal. Obstruksi merupakan suatu keadaan penurunan kapasitas fungsi paru yang diakibatkan oleh banyaknya timbunan debu sehingga menyebabkan kapasitas fungsi paru mengalami penurunan. Restriksi ialah suatu kondisi penyempitan saluran paru yang disebabkan oleh bahan-bahan yang memiliki sifat allergen, diantaranya debu, spora jamur, dan lain sebagainya. Terjadinya gangguan faal paru, baik obstruksi maupun restriksi dapat dipengaruhi oleh berbagai faktor, diantaranya faktor internal dan faktor eksternal.

Obstruksi jalan napas disebabkan oleh adanya peningkatan resistensi terhadap aliran udara. Penyebab dari peningkatan tersebut adalah keadaan di dalam lumen yang tersekat sebagian yang dikarenakan oleh sekresi berlebihan, penebalan dinding jalan napas karena adanya edema atau hipertrofi otot serta akibat lain di luar jalan napas misalnya sebagian parenkim paru yang rusak dan penyempitan jalan napas akibat hilangnya tradisi radikal. Penyakit obstruktif dinilai sangat lazim. Dalam negara maju seperti Amerika Serikat, penyakit ini merupakan penyebab kedua yang menyebabkan pengaman sosial setempat mengeluarkan biaya kecacatan setelah penyakit jantung. Penyakit ini juga merupakan penyebab mortalitas.

Restriksi memiliki kaitan dengan keterbatasan ekspansi paru, yang dikarenakan adanya perubahan pada parenkim paru atau adanya penyakit pada pleura, dinding dada dan alat neuromuskular. Berkurangnya kapasitas vital paru, menyebabkan proporsi $\mathrm{FEV}_{1}$ juga menurun, sehingga menyebabkan persentase $\mathrm{FEV}_{1} / \mathrm{FVC}$ menurun (West, 2010).

Timbulnya gangguan faal paru pada pekerja dalam waktu jangka panjang akan menimbulkan berbagai macam penyakit paru yang disesuaikan dengan kondisi paru. Penyakit paru yang dapat muncul diantaranya adalah Penyakit Paru Obstruktif Kronis (PPOK), misalnya emfisema, bronkhitis kronis dan asam serta beberapa penyakit restriktif diantaranya adalah penyakit yang ada pada parenkim paru atau fibrosis paru interstisial difus.

Pemeriksaan fisik apabila dilakukan pada penderita PPOK didapatkan hasil bentuk dada yaitu barrel chest atau dada menyerupai tong, diakibatkan inflasi berlebihan pada paru dan peningkatan diameter anteroposterior torax; cara bernapas penderita PPOK menyerupai seseorang yang meniup atau purse lips breathing; adanya penggunaan dan hipertrofi (pembesaran) otot bantu napas; pelebaran pada sel iga; didapati keadaan perkusi berupa hipersonor; dan ditemukan fremitus melemah, suara napas vesikuler melemah atau normal, ekspirasi memanjang, adanya mengi yang biasanya muncul saat eksaserbasi dan ronki.

Penderita penyakit restrktif memiliki tandatanda berupa penurunan kapasitas vital dan volume istirahat yang kecil, akan tetapi resistensi jalan napas sehubungan dengan volume paru tidak meningkat. Pemeriksaan fisik pada penderita restriktif didapati kondisi paru yang kaku, dinding dada penderita mengecil karena adanya daya tarik paru ke dalam yang lebih kuat, penyempitan pada sel iga dan pengecilan volume pada paru.

Menurut Siswanto dalam Fahmi (2007), menyatakan bahwa terdapat beberapa faktor yang mempengaruhi kesehatan seseorang akibat debu, yaitu kadar debu di udara, ukuran atau diameter debu, sifat debu, reaktivitas debu, cuaca kerja, lama waktu papar dan kepekaan individu. Kadar debu yang dimaksud adalah apabila kadar debu dalam udara semakin pekat maka akan semakin besar untuk timbul gangguan kesehatan serta terganggunya kenyamanan kerja. Ukuran atau diameter debu dapat mempengaruhi jenis gangguan pernapasan yang diderita seseorang, semakin besar partikel maka debu akan dapat masuk hanya pada saluran pernapasan atas saja, apabila ukuran debu semakin kecil maka dapat masuk sampai ke dalam alveoli. 
Sifat debu yang dapat mempengaruhi kesehatan seseorang dikarenakan debu memiliki sifat inert, fibrogenik serta karsinogen. Sedangkan, sifat reaktivitas dapat dibedakan menjadi 2, yaitu organik dan anorganik. Debu organik memiliki sifat kurang reaktif tetapi dapat menimbulkan reaksi allergik, debu anorganik lebih reaktif serta dapat menyebabkan reaksi iritasi. Cuaca kerja turut mempengaruhi kesehatan seseorang, cuaca kerja yang dimaksud merupakan lingkungan kerja. Sebagai contoh apabila lingkungan kerja panas dan kering dapat menimbulkan debu, dan debu yang ditimbulkan lebih reaktif.

Lama waktu papar merupakan lamanya waktu seseorang akan terpaparnya debu. Semakin lama waktu seseorang terpapar debu maka risiko memiliki kelainan paru lebih besar daripada seseorang yang memiliki waktu papar yang singkat. Kepekaan setiap individu berbeda antara satu dengan lainnya, dikarenakan faktor-faktor yang berbeda pula seperti morfologis, psikologis dan iritasi. Beberapa faktor internal individu seperti usia juga turut mempengaruhi.

Kondisi normal faal paru pada seseorang akan mengalami perubahan nilai fungsi paru secara fisiologi sesuai bertambahnya usia dan pertumbuhan paru (lung growth). Pada fase anak sampai seseorang berumur sekitar 22 sampai 24 tahun, pertumbuhan paru mulai terjadi. Pertumbuhan paru diiringan dengan semakin besarnya nilai fungsi paru. Nilai fungsi paru akan menetap (stationer), selanjutnya akan menurun secara gradual atau pelan-pelan pada usia sekitar 30 tahun. Penurunan nilai fungsi paru berupa KVP (Kapasitas Vital Paksa) dan FEV (volume ekspirasi paksa 1 detik pertama) dengan rata-rata $20 \mathrm{ml}$ setiap bertambahnya satu tahun usia seseorang.

Pekerja yang mangalami gangguan faal paru berasal dari kategori umur menengah dan matang. Menurut Khairiah (2013) umur merupakan faktor penting yang mempengaruhi timbulnya suatu penyakit secara langsung maupun tidak langsung, bersamaan dengan faktor-faktor yang lainnya. Faktor umur tersebut membedakan angka kesakitan dan angka kematian pada kelompok masyarakat. Seseorang dengan umur yang lebih tua maka akan semakin rentan untuk terserang penyakit dibandingkan dengan seseorang dengan umur yang masih muda. Hal tersebut dikarenakan kekebalan seseorang akan mengalami penurunan sesuai dengan bertambahnya umur.
Terdapat beberapa faktor yang mempengaruhi kapasitas fungsi paru, yaitu proses penuaan atau bertambahnya umur individu. Umur individu dapat mempengaruhi tingkat mortalitas dan morbiditas. Penurunan volume paru statis merupakan arus puncak ekspirasi maksimal daya regang dan tekanan $\mathrm{O}_{2}$ dalam paru. Pada individu dengan umur lebih tua menjadikan terjadinya penurunan atau pengurangan aktivitas refleks saluran napas. Hal tersebut menimbulkan berkurangnya kemampuan daya pembersihan saluran napas (Munawar, 2014).

Masa kerja dikategorikan menjadi 2, yaitu kurang dari 6 bulan dan lebih dari sama dengan 6 bulan. Kedua kategori masa kerja tersebut samasama memiliki pekerja dengan gangguan faal paru dengan frekuensi yang sama. Masa kerja merupakan salah satu faktor yang dapat menimbulkan gangguan kesehatan, khususnya gangguan saluran pernapasan.

Masa kerja yang diterima pekerja berhubungan dengan lamanya seseorang terpapar debu dalam kurun waktu tertentu. Masa kerja juga berhubungan dengan masa inkubasi debu berada dalam tubuh. Sehingga, apabila pekerja dengan masa kerja yang lama maka kondisinya akan berbeda dengan pekerja yang memiliki masa kerja yang singkat.

Lama paparan dikategorikan menjadi 2, kurang dari sama dengan 8 jam dan lebih dari 8 jam. Kategori tersebut berdasarkan Peraturan Menteri Tenaga Kerja dan Transmigrasi Nomor PER.13/ MEN/X/2011 Tahun 2011, yang menyatakan bahwa lama paparan yang diperbolehkan untuk kadar nilai ambang batas, yaitu 8 jam kerja setiap harinya. Sebagian besar pekerja PT X mengalami lama paparan lebih dari 8 jam.

Menurut Khairiah (2013), salah satu kerusakan yang disebabkan oleh debu merupakan akibat dari lama paparan atau kontak dengan debu. Pekerja yang mengalami gangguan faal paru sebagian besar merupakan pekerja dengan lama paparan lebih dari 8 jam. Semakin lama pekerja bekerja dalam tempat kerja tersebut memungkinkan pekerja mengalami lama paparan yang lebih lama dibandingkan dengan pekerja yang bekerja dengan lama paparan yang relatif lebih singkat.

Sebagian besar pekerja memiliki kebiasaan merokok dan merupakan perokok aktif. Namun, lama merokok dan banyaknya batang yang dikonsumsi berbeda setiap pekerja. Berdasarkan Tabel 2, menunjukkan bahwa pekerja yang tidak memiliki kebiasaan merokok memiliki kondisi faal 
paru yang normal. Seluruh pekerja dengan gangguan faal paru berasal dari pekerja yang memiliki kebiasaan merokok. Hal taersebut menunjukkan terdapat hubungan antara kondisi faal paru pekerja dengan kebiasaan merokok pekerja.

Gangguan faal paru yang dialami oleh individu dapat dipengaruhi oleh beberapa hal, diantaranya adalah merokok. Dalam kondisi masyarakat saat ini, merokok merupakan sesuatu hal yang wajar. Rokok yang dikonsumsi setiap harinya mengandung beberapa senyawa yang dapat membahayakan kondisi paru individu. Senyawa tersebut dapat mengendap dalam paru dan dapat menimbulkan perubahan fisiologi paru. Senyawa tersebut diantaranya adalah nikotin. Semakin lama waktu kebiasaan merokok menjadikan semakin banyak endapan yang ada dalam paru, sehingga jalur udara untuk keluar dan masuk menjadi lebih sempit.

Suma'mur menyatakan bahwa gangguan fungsi paru dapat dialami oleh seseorang disebabkan oleh lamanya individu terpapar pada lingkungan yang berdebu serta frekuensi yang dipaparkan secara bertahap, dan beberapa faktor internal yang mempengaruhinya, yaitu umur, jenis kelamin, masa kerja, status gizi, kebiasaan merokok, kebiasaan berolahraga, Alat Pelindung Diri (APD) dan lama paparan (Munawar, 2014).

Faktor-faktor yang mempengaruhi timbulnya gangguan faal paru saling berkaitan satu sama lain. Timbulnya gangguan faal paru tidak dapat hanya disebabkan oleh salah satu faktor saja, namun satu sama lain berkaitan dan berhubungan. Pengukuran konsentrasi kadar debu pada PT X dilakukan dengan menggunakan alat HVDS (High Volume Dust Sampler). Pengukuran dilakukan pada tiga titik. Tiga titik tersebut merupakan sumber debu, tempat aktivitas pekerja dalam melakukan pekerjaannya dan titik terluar dari tempat kerja. Titik tersebut dinamakan dengan titik A, titik B dan titik C.

Debu ialah suatu partikel zat kimia padat, yang ada disebabkan baik oleh kekuatan alami ataupun mekanis yaitu pengolahan, penghancuran, pengepakan secara cepat, pelembutan, peledakan dan lain sebagainya. Sumber debu dapat diperoleh dari benda organis maupun anorganis, seperti batu, kayu, bijih, logam, butir-butir zat, batu bara dan lainnya. Beberapa contoh debu diantaranya adalah debu kapas, debu asbes, debu batu, debu batu bara dan lain sebagainya. Debu memiliki sifat tidak berflokulasi (terkecuali dikarenakan gaya tarikan elektris), tidak berdifusi dan turun dikarenakan oleh gaya gravitasi atau gaya tarikan bumi (Suma'mur, 2009).

Debu berasal dari berbagai macam sumber, baik alami maupun buatan. Debu tersebut kemudian disebarkan melaui angin, letusan gunung berapi, pencemaran dan sebagainya. Debu udara dapat disebut juga sebagai aerosol dan memiliki tenaga radiasi lokal yang kuat dalam atmosfer serta dapat mempengaruhi iklim.

Menurut segi bahaya bagi kesehatan, debu dibagi menjadi 2 yaitu nuisance dust dan proliferative dust. Nuisance dust ialah debu yang dapat menganggu kenikmatan kerja, serta dapat menyebabkan iritasi kulit, selaput lendir, atau dapat menimbulkan endapan di mata dan hidung. Tetapi, debu jenis ini tidak menyebabkan fibrosis. Yang termasuk debu dalam jenis ini diantaranya adalah debu semen dan debu talk. Proliferative dust merupakan jenis debu yang dapat menimbulkan terjadinya fibrosis, serta menyebabkan berkurangnya elastisitas jaringan paru. Debu asbes dan debu semen termasuk dalam jenis ini ini.

Debu berdasarkan wujud kimia, dibedakan menjadi 2, yaitu debu organik dan debu anorganik. Debu organik merupakan debu yang berasal dari benda hidup. Yang termasuk dari debu organik adalah debu kayu, debu gandum, debu biji-bijian dan lain sebagainya. Sedangkan, debu anorganik merupakan debu yang berasal dari logam dan bukan dari logam. Debu anorganik yang berasal dari logam sebagai contohnya adalah debu timah hitam, debu timah putih dan lain-lain. Debu anorganik yang berasal bukan dari logam diantaranya adalah debu batu bara, jenis debu yang mengandung silikat, silikat karbonat dan lain sebagainya.

Debu atau partikel aerosol dapat masuk dalam tubuh dengan jalan melalui saluran pernapasan atau saluran inhalasi. Debu atau partikel kemudian terabsorbsi ke dalam saluran pernapasan bergantung pada beberapa hal, diantaranya adalah kecepatan aliran darah dalam paru, sifat kepolaran gas dan ukuran partikel. Absorpsi suatu partikel melalui paru kecepatannya dapat berjalan cepat dikarenakan kondisi dinding paru (selapis sel alveoli) yang tipis dan berhadapan dengan dinding kapiler darah, serta ukuran luas permukaan paru (Tualeka, 2013).

Menurut Tualeka (2013), ukuran debu dapat dibagi menjadi 3 berdasarkan absorpsinya ke dalam paru, yaitu debu kurang dari 1 mikron, 1 sampai 5 mikron dan 5 sampai 30 mikron. Debu dengan ukuran kurang dari 1 mikron yang diabsorpsi melalui saluran pernapasan dapat mencapai alveolus. 
Selanjutnya diabsorpsi dalam sistem darah atau tubuh akan melakukan pertahanan seluler. Pertahanan seluler dilakukan oleh sel linan (mikrofag) dengan jalan menelan partikel tersebut.

Debu yang berukuran 1 sampai dengan 5 mikron apabila masuk ke dalam saluran pernapasan diendapkan dalam trakea, bronkhus dan bronkhiolus yang mempunyai lendir, lembab dan memiliki silia yang menyerupai rambut halus. Silia bertugas mencambuk partikel yang masuk tanpa henti, kemudian menggerakkan lendir secara perlahan keluar dari paru. Partikel dan lendir yang terperangkap di dalamnya kemudian dapat ditelan atau malah dikeluarkan dari tubuh melalui cara batuk. Pernyataan tersebut disebut dengan pertahanan fisik /mekanik atau mekanisme bersihan mukosiliar.

Debu dengan ukuran partikel 5 sampai 30 mikron yang masuk ke dalam tubuh akan mengendap pada saluran pernapasan atas, terutama dalam nasofaring (rongga hidung) dan tenggorokan. Kemudian, partikel tertelan bersama lendir yang selanjutnya akan diserap melalui epitel saluran cerna.

Sumber debu yang ada dalam PT X tidak dapat terklasifikasikan secara khusus. Sumber debu didapatkan dari campuran berbagai sumber yang dihasilkan dari proses pembangunan gedung bertingkat yang diselenggarakan oleh PT X. Salah satu proses penyebab sumber debu merupakan proses finishing. Proses finishing ialah proses akhir dari pembangunan sarana fisik, yang meliputi pengecoran, pengacian, pengecatan dan lain sebagainya.

Proses finishing berkaitan dengan beberapa material yang menghasilkan debu, yaitu debu semen, debu hebel atau bata ringan dan debu pasir. Material tersebut menjadikan pekerja merasa terganggu akan adanya debu tersebut. Pekerja menyatakan bahwa mengeluhkan beberapa keluhan terkait dengan saluran pernapasan, seperti batuk dan juga menganggu kesehatan mata berupa munculnya keluhan iritasi mata. Pekerja tidak hanya mengeluhkan keluhan saluran pernapasan dan kesehatan mata, namun para pekerja di PT X menyatakan bahwa sering menemukan dan melihat debu dalam area proyek PT X.

Berdasarkan hasil pengukuran kadar debu di PT $\mathrm{X}$, menunjukkan bahwa ketiga pengukuran tersebut masih berada di bawah Nilai Ambang Batas (NAB). Hasil rata-rata yang dihitung berdasarkan ketiga pengukuran juga masih berada di bawah NAB. Yang berarti bahwa konsentrasi kadar debu dalam proyek PT X masih berada dalam baas normal sesuai dengan NAB yang telah ditentukan. Nilai Ambang Batas yang dimaksud berada dalam Peraturan Menteri Tenaga Kerja dan Transmigrasi Nomor PER.13/ MEN/X/2011 tentang NAB faktor fisika dan kimia di tempat kerja. NAB juga ditentukan dalam SNI 190232-2005 tentang NAB zat kimia di udara tempat kerja.

NAB merupakan standar pemaparan kerja berupa pedoman kualitatif dan kuantitatif terhadap penerapan dan perlindungan kesehatan bagi tenaga kerja terhadap efek pemaparan kerja. Penerapan NAB dalam lingkungan kerja yaitu NAB faktor kimia dan faktor fisika. Berdasarkan penerapan NAB dalam lingkungan kerja bertujuan agar masyarakat mempunyai pedoman yang pasti perihal keamanan dan kenyamanan mengenai lingkungan kerjanya (Suma'mur, 2009).

Berdasarkan ketetapan peraturan menteri Permenakertrans Nomor PER. 13/MEN/X/2011, menetapkan NAB debu menjadi 2 golongan, yaitu debu respirabel dan debu inhalabel di tempat kerja. Debu respirabel merupakan partikel debu yang dapat apabila terhirup dapat masuk sampai ke dalam organ terdalam saluran pernapasan yaitu alveolus. Sedangkan, debu inhalabel merupakan jenis debu yang apabila masuk ke dalam saluran pernapasan maka hanya akan mengendap pada saluran pernapasan atas.

Nilai Ambang Batas (NAB) yang ditetapkan untuk debu respirabel pada lingkungan kerja sebesar $3 \mathrm{mg} / \mathrm{m}^{3}$. Artinya, bahwa batas toleransi jenis debu respirabel apabila terhirup oleh saluran pernapasan sebesar $3 \mathrm{mg} / \mathrm{m}^{3}$. Sedangkan, NAB untuk jenis debu inhalabel di lingkungan kerja adalah $10 \mathrm{mg} / \mathrm{m}^{3}$. Yang berarti bahwa batas toleransi manusia apabila terhirup adalah sebesar $10 \mathrm{mg} / \mathrm{m}^{3}$. Baik NAB debu respirabel dan debu inhalabel, akan diperbolehkan dengan catatan pekerja yang terpapar selama 8 jam tiap harinya atau 40 jam satu minggunya tanpa menimbulkan gangguan kesehatan atau penyakit.

Penelitian yang dilakukan oleh Triatmo dkk (2006) dalam Munawar (2014), menyatakan bahwa paparan debu adalah salah satu faktor risiko yang dapat menyebabkan timbulnya gangguan fungsi paru. Partikel debu dengan ukuran lebih besar dari 50 mikron dapat dlihat oleh mata telanjang, sedangkan debu dengan ukuran kurang dari 10 mikron sulit atau tidak dapat terdeteksi oleh mata apabila terdapat pantulan cahaya yang kuat yang 
berasal dari partikel debu tersebut, atau dapat dilihat dengan menggunakan mikroskop (Fahmi, 2007).

Berdasarkan pernyataan di atas, menunjukkan bahwa partikel debu yang berada dalam PT X merupakan partikel debu dengan ukuran lebih besar dari 50 mikron karena pekerja dapat melihat dengan mata telanjang. Sedangkan, berdasarkan jenis debunya, maka sumber debu pada PT X dapat dikategorikan masuk ke dalam jenis nuisance dust dan proliferative dust.

Tenaga kerja dalam melakukan pekerjaanya akan mendapat pemaparan kerja dari berbagai faktor yang ada dalam lingkungan kerjanya. Pemaparan kerja merupakan suatu kondisi di mana dalam pekerjaannya seorang tenaga kerja menghadapi satu atau lebih faktor yang memungkinkan mempengaruhi tingkat kesehatan dan keselamatan diri pekerja tersebut (Suma'mur, 2009).

Faktor yang mempengaruhi pekerja diantaranya merupakan faktor kimia. Akibat pemaparan kerja tersebut dapat bersifat positif dan negatif. Akibat positif yang ditimbulkan menjadikan pekerja mengalami suatu kelebihan atau manfaat dalam diri pekerja. Namun, apabila dampak negatif yang ditimbulkan menjadikan pekerja mengalami pengurangan atau kemunduran pada diri pekerja, contohnya adalah menurunnya derajat kesehatan pekerja.

Dampak negatif yang tidak dikehendaki tersebut harus segera dilakukan suatu pencegahan. Dampak yang ditimbulkan bergantung pada kualitas dan kuantitas paparan zat ataupun berbagai faktor dalam lingkungan kerja. Salah satu faktor yang berada dalam lingkungan kerja ialah debu.

Dampak negatif yang ditimbulkan debu tersebut diantaranya timbulnya gangguan saluran pernapasan, baik saluran pernapasan atas maupun saluran pernapasan bawah, bergantung pada ukuran dan bentuk dari partikel debu tersebut. Munculnya penyakit-penyakit yang menyerang paru juga merupakan salah satu dampak negatif. Penyakit paru menurut Suma'mur (2009) adalah pnemokoniosis yang didalamnya terdapat silikosis, antrakosis, asbestosis, berilosis, siderosis dan lain sebagainya. Kemudian terdapat penyakit paru dan saluran pernapasan (bronkhopulmoner) yang disebabkan oleh debu logam keras; debu kapas, vlas, henep dan sisal (bissinosis); asma akibat kerja dikarenakan sensitivitas dan zat perangsang dalam proses pekerjaan; alveolitis allegika dikarenaka faktor luar akibat menghirup debu organis; dan kanker paru atau mesotelioma akibat asbes.

Debu yang mengganggu tersebut dapat dicegah atau dimanimalisir dengan menggunakan pengendalian risiko dalam upaya pencegahan. Menurut Suma'mur (2009), lima tahap pengendalian risiko dalam upaya pencegahan kecelakaan adalah eliminasi, substitusi, engineering (rekayasa), administratif dan Alat Pelindung Diri (APD). Tahapan pertama adalah eliminasi, yakni menghilangkan faktor risiko. Sedangkan, tahapan kedua merupakan substitusi atau mengganti faktor risiko. Tahapan selanjutnya merupakan tahapan rekayasa, yaitu merekayasa faktor risiko. Tahapan keempat selanjutnya adalah tahapan administrative dan tahapan yang terakhir merupakan pemakaian dan penggunaan Alat Pelindung Diri (APD).

\section{SIMPULAN}

Konsentrasi kadar debu pada PT X selaku perusahaan konstruksi masih berada di bawah Nilai Ambang Batas (NAB) berdasarkan Peraturan Menteri Tenaga Kerja dan Transmigrasi (Permenakertrans) Nomor PER.13/MEN/X/2011 Tahun 2011 tentang NAB faktor fisika dan kimia di tempat kerja. Hasil pengukuran yang masih berada di bawah NAB tersebut termasuk pengukuran pada ketiga titik maupun hasil rata-rata pengukuran tiga titik tersebut. Dengan hasil pengukuran dan rata-rata yang masih di bawah NAB maka konsentrasi kadar debu di area proyek PT X dapat dikatakan masih normal.

Namun, dengan konsentrasi yang masih normal, masih terdapat beberapa keluhan subjektif pekerja yang meliputi keluhan saluran pernapasan seperti batuk serta keluhan iritasi mata. Pekerja juga mengeluhkan bahwa sering melihat dan menemukan debu yang mengganggu proses kerja dari pekerja. Beberapa pekerja PT X mengalami gangguan faal paru berupa obstruksi ringan dan restriksi ringan. Timbulnya gangguan faal tersebut dipengaruhi oleh kebiasaan merokok yang dimiliki pekerja.

Meskipun kadar debu pada area proyek PT X masih di bawah NAB, namun pekerja diharapkan melakukan tindakan pencegahan dengan menggunakan masker saat bekerja, serta pekerja yang memiliki kebiasaan merokok diharapkan mampu secara perlahan dan bertahap untuk mengurangi banyaknya batang rokok yang dikonsumsi setiap harinya. 


\section{DAFTAR PUSTAKA}

B. West, John. 2010. Patofisiologi Paru Esensial Edisi 6. Penerbit Buku Kedokteran EGC. Jakarta.

Departemen Hukum, RI. 1999. Undang-Undang Nomor 18 Tahun 1999 tentang Jasa Konstruksi.

Fahmi, Wildana. 2007. Hubungan Paparan Debu, Umur, Masa Kerja dan Pemakaian APD Terhadap Timbulnya Gejala Gangguan Saluran Penapasan di PT PAL Indonesia (Persero). Skripsi. Surabaya: Universitas Airlangga.

Hidayat, Wayu. 2007. Faktor-faktor Risiko yang Menyebabkan Rendahnya Produktivitas Tenaga Kerja pada Pelaksanaan Pekerjaan Konstruksi. Skripsi. FT UI.

Imaduddin, Ahmad. 2012. Hubungan Karakteristik Pekerja dengan Keluhan Gangguan Pernapasan Akibat Paparan Debu Kapas. Skripsi. Surabaya: Universitas Airlangga.

Kemenakertrans, RI. 2011. Permenakertrans Nomor PER.13/MEN/X/2011 Tahun

2011 tentang NAB Faktor Fisika dan Kimia di Tempat Kerja.

Khairiah. 2013. Analisis Konsentrasi Debu dan Keluhan Kesehatan pada Masyarakat di Sekitar
Pabrik Semen di Desa Kuala Indah Kecamatan Sei Suka Kabupaten Batu Bara. Skripsi. Medan: FKM Universitas Sumatera Utara.

Munawar, Samik. 2014. Analisis Pengaruh Paparan Debu Kayu terhadap Faal Paru. Tesis. Surabaya: Universitas Airlangga.

Rahman, Abdur, Atrisman Nukman, Setyadi, Carolina Rusdy Akib, Sofwan dan Jarot. 2008. Analisis Risiko Kesehatan Lingkungan Pertambangan Kapur di Sukabumi, Cirebon, Tegal, Jepara dan Tulung Agung. Jurnal. Ekologi Kesehatan Vol. 7 No 1, April 2008: 665-677.

Rohim Tualeka, Abdul. 2013. Toksikologi Industri \& Risk Assessment. Graha Ilmu Mulia. Surabaya.

Sholihah, Mardliyatus. 2014. Hubungan Paparan Debu Dengan Faal Paru Pekerja Di PT Konstruksi X Surabaya. Skripsi. Surabaya: Universitas Airlangga.

Suma'mur, P.K. 2009. Higiene Perusahaan Dan Kesehatan Kerja (HIPERKES). Sagung Seto. Jakarta.

Yulaekah, Siti. 2007. Paparan Debu Terhirup dan Gangguan Fngsi Paru pada Pekerja Industri Batu Kapur. Tesis. Semarang: Universitas Diponegoro. 